\title{
Distant Education: Online Learning for Civic Education
}

\author{
Riza Alrakhman $^{1}{ }^{*}$, Dasim Budimansyah ${ }^{2}$, Sapriya Sapriya ${ }^{3}$ \\ ${ }^{1,2,3}$ Universitas Pendidikan Indonesia \\ ${ }^{*}$ Corresponding author.Email: rizapkn@upi.edu
}

\begin{abstract}
This paper examines online learning in civic education using distance education. Online learning has become more rapid when Corona Virus Disease 19 (COVID 19) hit Indonesia. Online learning demands efficiency for educators and students to develop independent studying. Using technology for educational purposes is not a brand-new thing technology development has become part of human society. Information became rapid as digital technology advanced. Online learning for civic education becomes a challenge that needs balance for morals and knowledge at the same time. This research is researching the method using for civic education using distant learning in higher education. As an adult, college students demand self-discipline in studying and how online learning can help stimulate student self-discipline as developed responsibility. There are three kinds of think at distance education first program for distance education, the second unit that separate institution and program, and the third institution that dedicated all the activity for distance education. Distance education demands understanding the source, design, delivery, interaction, and learning environment that involves this to ensure that the goal of civic education can be achieved. Therefore, distance education through online learning needs an educator to develop the best system to ensure students get a learning experience.
\end{abstract}

Keywords: Civic Education, Distance Education, Online Learning, Self-Discipline.

\section{INTRODUCTION}

Corona Virus Disease (COVID-19) tragedy that happens almost worldwide has made many sectors collapse. This tragedy had brought civilization to a brandnew dimension of life that force a massive change to the way of living. Education is not an exception that must adapt to a new situation so that the purpose of education can still be running in this kind of situation. In Indonesia, this has made all education systems had to use distance education as a platform for teaching as the policy of social distance made. In reality, distance education itself is not a brand-new design distance education has become part of the education system in recent years. Technology development has made the education system change its learning paradigm. Society has developed toward another level, so education must be prepared to transform at the most fundamental level [1]. Distance education as a platform for education is an answer to a new society that based their daily lives on the digital platform. As we know these days, people cannot be separated from their digital world, which has become part of their lives. Distance education does not result because of a critic of citizens, school board, and government. It is part of social evolution how education provides the skill to survive in the developed world [1]. In the case of COVID-19, the urgency of distance education has become more vital. It has made many universities developed their platform to support the system. An educator must design an education that supports distance education, in this case, is civic education. The curriculum system has to be adjusted that suit distance education, the combination of technology, and human resources itself.

Civic education in Indonesia as compulsory at higher education has the primary purpose of making good, and smart citizenship [2] makes civic education essential as value education. As one of the educations that study is about how to live as a society, civic education must understand the student how to be able to face this kind of situation. How to combine technology and human to be made balance which a distance education the role of educator became essential to stimulus learning environment and bring education system to another dimension. Civic education also became important for giving the right mindset facing a new kind of environment that happen because of COVID-19 the young generation has "...to think and care about the 
welfare of the community (the commonweal or civitas) and not simply about their own individual well-being" [3] which is needed for facing COVID-19 they must have a concern about what happened to their society as part being of the citizen to develop the mindset toward the well-being of all. This mindset becomes essential as the citizen must face this as a unity as part of civic education to learn to live as a citizen to sacrifice their self-interest for the sake of the common good.

Using technology development is necessary for distance education because learning through distance education is related to technology. Many media can be used for distance education, such as video recordings that need some skill to operate. This means that the lecturer must learn the new technology needed to support their learning environment using a program that connects to the internet. Online media these days has become common and became part of human society but using it for education purposes needed great care. The essential part is to maintain the rules so the purpose of education that has been made can be achieved, which need skill for using the program, so it does not miss the purpose.

\section{THEORETICAL REVIEW}

\subsection{Distance Education Definition}

Distance education is where students and teachers are separated by distance or time [4]. This means that first, the student and teacher separate by distance but use media technology and then teach simultaneously. This method gives the student the same experience with a contemporary model of studies where the teacher talks to students in the classroom. The second is teacher and student separate by time, which need an artificial communication medium that will provide a medium to deliver information and provide Chanel for teacher and students to interact. In the case of time is need more strategy than using the live method. A medium must be designed to build a communication that ensures that the lecturer's information is not missing. Wich the help of technology development, a program is used as a medium through the internet for students to access it every time, and the teacher can provide feedback.

Distance education, according to Moore, M. G., \& Kearsley, $G$ is plan learning that occurs in a different place from teaching, as a result, requires special techniques of course design, a unique method by using technology [4] such as the internet that in recent year has become as part of basic need in human life these days. With technology development, the distance education gap can be overcome, the distance education relation can be maintained differently [2]. The use of technology for distance education is becoming essential using the statement of Telecommunication Council (ITC) "leadership, information and resources to expand and enhance distance learning through effective use of technology" [5]. Examples of the technology used for distance education are the internet, computer program, zoom, google Mets, bigbluebutton, Microsoft team, YouTube, and many more. Distance education is not about technology, but technology use cannot avoid because of the consequences of subjects for a course design and delivery. The main reason is the distance between student and teacher rather than meet in the classroom. The primary purpose is maintaining information and communication as a teacher gives longdistance guidance [6].

\subsection{Civic Education definition}

The most pervasive and clearly recognizable change in teacher education in the past decade is the method, material, and equipment developed through time [7]. Developed civic education in the 21 century is a tacking account about the local national, and global community and their concern [8]. In Indonesia, civic education is as compulsory that state law of Indonesian about higher education No 12 of 2012 the purpose of civic education is to make seen of nationality and patriotism [9]. The main point of civic education in Indonesia education program about democracy and expand with another source of knowledge that has a positive impact, such as the environment developed through society and family to developed critical thinking, analytical to prepare their life in a democracy that bases on Pancasila and 1945 Constitution of The Republic of Indonesia [10].

Pancasila explains five principles 1) Belief in the One and Only God. 2) Just and Civilized Humanity. 3) The unity of Indonesia. 4) The sovereignty of the People Led by the Inner Wisdom of Deliberation among Representatives. 5) Social Justice for the Whole of the People of Indonesia. This value is also written at the preamble 1945 Constitution of The Republic of Indonesia, making Pancasila the basic ground for Indonesia. So based on the Pancasila precepts, distance education is made for citizenship education that develops human values and civilized justice.

Civic education in Indonesia is essential to make the student understand their national interest and moral education. In John J. Cogan, \& Ray Derricott civic education is classified into five categories: a sense of identity, the enjoyment of a certain right, the fulfillment of corresponding obligations, a degree of interest and involvement in public affairs, and acceptance of societal value [8]. Civic education in Indonesia refers to the development of national character [11]. Students as citizens are demanded to live together and become useful for their society and face change in the future. It is necessary to master knowledge, technology, and art based on religion, morals, Humanity, and their local wisdom [12]. This is based on Indonesia's ideology 
Pancasila that has come from their own life and culture. It is the ways Indonesian people live based on their understanding of their history and how their ancestor's life they live [13]. With civic education, the student learning about history, society, democracy, Pancasila, Humanity, moral, government, politic, their local wisdom, and responsibility and right.

\subsection{Online Learning}

In recent years, Internet users have become part of daily life, with internet users growing their education and using the internet for media learning. Where there is still an ambiguous statement about online learning [14], such as what is related to distance education. In distance education, students are separated by space or time [4]. The delivery technique for distance education is variated; it can also use online learning. Garrison subscribes to online learning as a learning environment that provides social presence, cognitive presence, and teaching presence [14]. While Buchen says that online learning is a delivery system "transcended the gaps between traditional face-to-face learning and distance learning" [15]. Online learning is connectivity, flexibility, and the ability to promote varied interactions [14]. So distance education is not always related to the internet connection, but in online learning, connectivity to the internet is the medium that is used to give a learning experience.

With the rapid use of internet users, "According to the OLC's annual reports from mid-2000, nearly 3.5 million people have taken online courses already" [16]. This data proves the coloration of online learning with the internet user and massively developed to internet access. Online learning itself is still in the developed phases "...it remains a relatively new medium for teaching and learning that is constantly being improved based on research" [17]. This happens because the lecture first has to master the technology used for online learning; not only the lecture but students also must learn to use the technology. The delivery system is also necessary for online learning is not about moving conventional schools and became online. The primary goal for online courses is the creation of communities of learners [18]. Cannell says Traditional face-to-face courses do not guarantee community any more than distance learning courses do [18]. So in online learning, communication is essensial for online learning to work, which can build based on online learning through online media.

\subsection{Self Discipline}

With the development of distance education, more universities add distance education to their system, and self-discipline is one of the main keys to success in distance education [19]. Only with Self-discipline and motivation student can have significant coloration with the score [19]. Self-discipline is made student meet the demanding deadline in their course, so self-discipline is a willingness that came from their self to be discipline with the demand that give to them, in this case, is a deadline of the assignment, "Self-discipline is not the ability to accomplish goals which others deem desirable. Rather, self-discipline is the ability to marshal willpower to accomplish goals and uphold standards that one personally regards as desirable." [20] so distance education learning must provide the student motivation that needs for them to have a goal to achieve and desirable, and become their regards as desirable for the student.

Discipline in distance education is a major concern is related to how the learning process runs effectively. Many students failed in distance education learning because of a lack of discipline. Stanley T. Dubelle "selfdiscipline: helping student behave responsibly" [21] is about how the student can make a better decision in the learning process. To able to set priority what is essential for them. In self-discipline, students able to control themself and finish what has become their responsibility. Stanley T. Dubelle says to create self-discipline is like coaching in class [21] so in distance education, it is also related to the lecture on how they can maintain discipline with the time commitment given. Self-discipline in distance education is related to lecturers, where students can lose motivation if the lecturer does not have the discipline to check student activity in time.

\section{METHOD}

The methodology of this research is using qualitative, using media online method as questioner to Universitas Terbuka (UT) Or Indonesia Open University (IOU) as one of the main purposes of the education is using distance education and universities in Indonesia that using distance education because of the impact of COVID-19. This essay chooses to provide data through an online questioner because of the social distance rule and the primary research that focused on social distance education. The advantage of online survey is "the virtual elimination of paper, postage, mail out, and data entry costs; reduced implementation time; reduced surveying costs once an electronic data collection system is developed is in place; data display and tabulation simultaneous with completion of surveys; availability of data in graphic and numerical format; easy to send reminders to non-respondents; and simplicity of importing data into data analysis programs" [22]

The respondents are chosen from the student who has taken a civic education course to know how the online implementation learning they have taken and how it is used. Most of the students are from Indonesia Open 
University. They were chosen because of the university program that solely focuses on distance learning education. Besides questionary as a primary database, the literacy review also collects data and supports the statement made. The lecture interview method is used to learn about the education process in Indonesia Open University in eight weeks. Civic education course is divided into eight sections into every section lecture giving discuss topic every week for the student to respond dan lecture and peers also give their respond, besides that three assignment also given to the student at the end of the course the final exam given to the student. So, the data gathering is done in eight weeks based on the civic education course in Indonesia Open University.

\section{RESULT AND DISCUSSION}

\subsection{Distance Education for Civic Education}

Moore, M. G., \& Kearsley, G say three kinds at distance education first distance learning program, the second distance learning unit, three distance learning institution [4]. The first distance learning program has added a system for their student to learning off-campus where student can access the program that has made available in modern technology it can use such as video conference and multimedia information that can be accessed through the internet. The second a special separated unit that usually has an administration to maintain the stability of distance education. The threedistance learning institution where all activity is is exclusively to distance education. When the Covid-19 virus outbreak, many universities already have a separate unit for distance education, but they are not maintained regularly as part of the support system for conventional education. They have the platform but not purposely to make the university become a distance learning. This situation with the Covid-19 pushes the separate unit to be more active to make distance education more efficient.

Indonesia Open University, also known as Universitas Terbuka (UT), is chosen to be the main research because this university whose sole purpose is to developed distance education. Even before the outbreak of Covid-19. When the other university is developed their distance education system mainly because of the Covid19 outbreak, the research can have cooperation between a university that focuses on distance education and a university that used distance education because of the situation. It not that the university that is now using distance education does not have a distance education system, many of the university has open access for the student to learn through their website. So for all the universities, distance education is not a brand new concept.
So to make distance education system, many steps must be fulfilled if the university one to adapt wholely. There has to be a system model that needs much expertise involved because not all lecture able to operate the program, and the programmer does not know the major that developed by the lecture, so corporation must be done to make a platform for every course that will be taken by a student this show how much effort is needed. Design a course an attractive course is more challenging which involves graphics designers for the outlook only that usually lecture does not have that skill, and they must cooperate to make sure the primary course purpose can be achieved because all of the course has different variables and different achievement. The figure below is adapted based on Moore, M. G., \& Kearsley, G. (1996) for better understanding. "Distance education: A systems view" the figure will show the step star with source, design, interaction, and learning environment to make a distance education:

Figure 1. System Model For Distance education

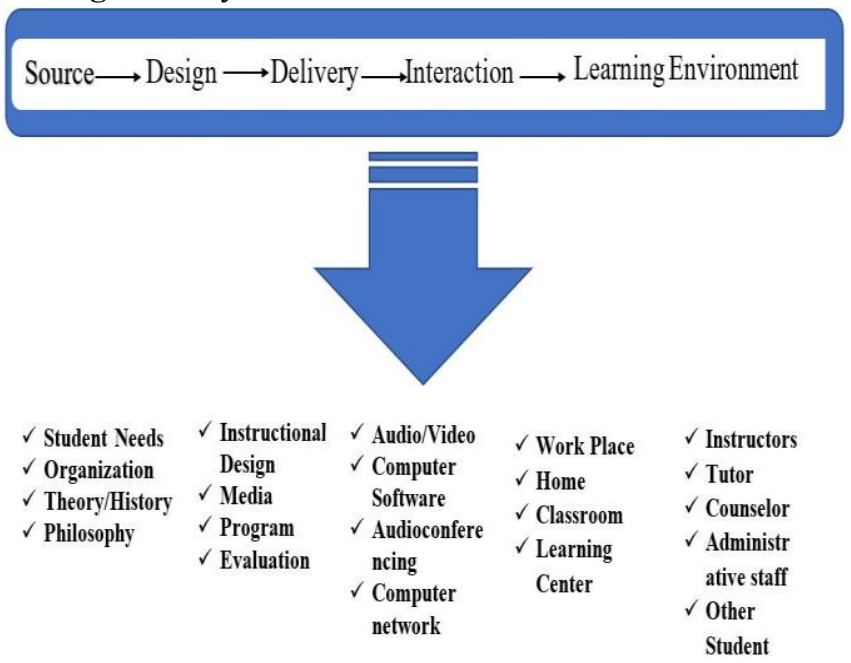

Civic education is a compulsory course, so every faculty has the responsibility to study civic education. At UT their used Moodle platform as its learning management system (LMS). The civic education course is divided into eight-session that last for eight weeks. Each session is provided with a topic and three assignments that have to be submitted in paper form, and then students are divided into a virtual classroom with one tutor to manage the class. Online learning for civic education at UT has a variety of students, most of whom are adults who work, where the adult student the process of learning is about the experience and not about what they are learning from theory [23], learning experience through learning group discussion that can make many communications happen between student is more suitable for adult. Using Community of Inquiry (CoI) Garrison et al., there is three-element for distance education 1) social present, 2) teaching present, 3) cognitive presence [24].

Social presence is a student as a participant and made interaction learning through class learning. In the case of 
civic education at UT, the social presence is the ability of the student to communicate through an online platform. The theme used by the lecture to make a platform for communication is a variety of discussions in the scope of civic education. There are eight themes in civic education at UT: introduction of urgency for civic education, geopolitics, national resilience, national integration, national identity, right and obligation, democracy, and constitution. The discussion is made based on themes that present each week that the student must discuss

Teaching present is a lecture that provides planning, facilitator, and guidance for students. With this, the lecture can maintain learning achievements in the case of civic education where there is moral and value involved as Mezirow say that learning experience can facilitate the transformation from their environment [25]. Adult learning can occur outside of formal education, such as popular culture [26], which is suitable for distance education where the student has become part of society. In this case, the lecture can develop many case studies that happen in their environment to develop an awareness of moral and value importance. This day technology is part of human society, so building awareness and selfcontrol is necessary for facing the digital world's impact; as Licona says, self-control is the power to resist temptation [27]. In the digital world, students' information depends on the self and can control their actions in the digital world.

Cognitive presence is which learners can construct and confirm meaning through sustained reflection and discourse in a critical community [24]. With online learning, the student is expected to build an active discussion that can construct critical communication through their experience in the discussion community that the lecture has made. This communication is to build civic skill, civic disposition, and civic knowledge. A pedagogical approach through the curriculum constructs this scheme. Discussion is made available for students and lecturers to interact with themes that the lecture has made that sync with the curriculum. Besides the discussion, there is also material review that students can access all the time; it can be module or video recorded. The online learning experience is able to make the student aware of the current condition in the nation and constructs knowledge and skill as a citizen. The assignment is not only provided knowledge also moral responsibility, to be honest with their work. Davis Office of Student Judicial Affairs (2008) asserts that academic integrity exists when every academic member seeks knowledge honestly, fairly, with mutual respect and trust, and accepts responsibility for their actions and the consequences of those actions [28]. The academic environment must support honesty, fairness, respect, trust, and responsibility made available by a commitment through their educational approach.

\subsection{Student Respond Using Distance Education}

The process of distance education, in general, is based on the technology used to deliver education so that the learning experience can still be intact where the conventional classroom is moving to the digital platform. Clearer image can be seen in the figure below:

Figure 2. Online Learning Method for Civic Education

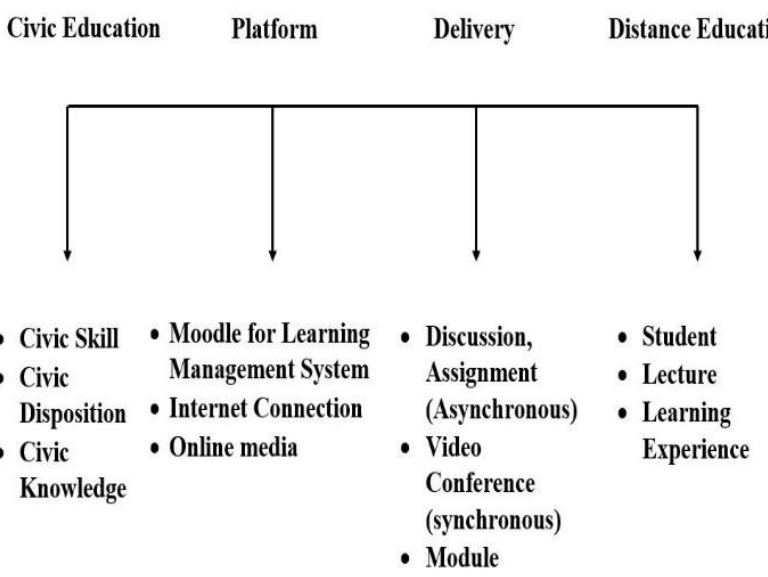

A delivery process on distance education is the key in distance education. In the process of learning, students want the lecture to be active to give a reply when an assignment has been submitted. A lack of response can give students a loss of motivation when a student needs discussion with the lecture, but the lecture gives their response one week later, making them feel demotivated. A lack of response from their peer also makes students wait for their reply to see other responses first; this also makes the lecture not have discussed to reply that made them wait for another student that sometimes takes time. So, the lecture can help motivated students with their fast response, and interesting themes can also make students want to reply fast because they like the theme being discus. Not every learning using synchronous method lecture also give an online video conference this can give the student real-time for discussion with lecture, but sometimes both student and lecture has bad reception that can make video conference became not effective. So, in this case, the student feels that an asynchronous mode is safe because they can prepare their reply anytime, anywhere. Based on the questionary report that has been given to the student that has taken a civic education course. The table below will show how is the result of the distance education for civic education.

Table 1. Student Responds to Distance Education for Civic Education

\begin{tabular}{lll}
\hline Category & Feedback & $\begin{array}{l}\text { Student } \\
\text { Respond } \\
\text { Example }\end{array}$ \\
\hline Motivation & $\begin{array}{l}\text { Lecture and Peers } \\
\text { can give }\end{array}$ & $\begin{array}{l}\text { An active lecture } \\
\text { gives students } \\
\text { motivation to also }\end{array}$ \\
\hline
\end{tabular}




\begin{tabular}{|c|c|c|}
\hline & & $\begin{array}{l}\text { active in the } \\
\text { learning process. } \\
\text { Students became } \\
\text { more motivated } \\
\text { when seeing their } \\
\text { peer's activity in } \\
\text { the online class. }\end{array}$ \\
\hline $\begin{array}{l}\text { Motivation } \\
\text { is essential }\end{array}$ & $\begin{array}{lr}\text { Learning } & \text { using } \\
\text { online } & \text { learning } \\
\text { can } & \text { become } \\
\text { boring } & \end{array}$ & $\begin{array}{l}\text { Students feel that } \\
\text { they need the } \\
\text { motivation to } \\
\text { learn through } \\
\text { online learning. } \\
\text { Content and } \\
\text { themes can } \\
\text { motivate the } \\
\text { student. }\end{array}$ \\
\hline $\begin{array}{l}\text { Distance } \\
\text { education } \\
\text { learning } \\
\text { delivery }\end{array}$ & $\begin{array}{l}\text { Synchronous and } \\
\text { Asynchronous }\end{array}$ & $\begin{array}{l}\text { The student feels } \\
\text { that } \\
\text { asynchronous is } \\
\text { safer than } \\
\text { synchronous. In } \\
\text { synchronous } \\
\text { methods, internet } \\
\text { signals } \\
\text { sometimes } \\
\text { become problem } \\
\text { and make } \\
\text { information that } \\
\text { gives the lecture } \\
\text { unclear. }\end{array}$ \\
\hline $\begin{array}{l}\text { Lecture } \\
\text { Method }\end{array}$ & $\begin{array}{l}\text { The method use } \\
\text { by the lecture is } \\
\text { essential for } \\
\text { developed interest }\end{array}$ & $\begin{array}{l}\text { The lecture } \\
\text { method made the } \\
\text { learning process } \\
\text { became } \\
\text { interesting. }\end{array}$ \\
\hline $\begin{array}{l}\text { Civic } \\
\text { Education }\end{array}$ & $\begin{array}{l}\text { Democracy, } \\
\text { human right, the } \\
\text { rule of law }\end{array}$ & $\begin{array}{l}\text { Many } \\
\text { information can } \\
\text { be gained through } \\
\text { media, with this } \\
\text { student feel they } \\
\text { know their } \\
\text { nation. } \\
\text { guidance is need } \\
\text { because they feel } \\
\text { some information } \\
\text { is valid and others } \\
\text { are a hoax. } \\
\text { Many } \\
\text { information } \\
\text { through media } \\
\text { can motivate } \\
\text { them, such as } \\
\text { nationalism. }\end{array}$ \\
\hline
\end{tabular}

Communication through distance education is essential to build a learning environment Students and lectures are separated by distance and time. Students sometimes have to wait for lecture guidance with their discussion, but they can lose interest if they wait too long. Discipline is also needed in distance education both student and lecture have committed to the schedule. For lecture and students who have never used Moodle system, they have to master the program first, so it not became a problem, such as taking much of their time. To maintain academic integrity, such as knowledge honestly, fairly, and responsibility, all assignment that gives by student mush check by their lecture, so the student did not cheat many cases shows is about plagiarism, the student is reminded before submitting all their assignment to follow all the instructions that have been given such as rules about plagiarism.

\section{CONCLUSION}

Distance education can give a solution in the case of Pandemic Covid-19 but for that need a delivery system that can provide a learning experience. In the case of civic education, a learning experience must also be able to stimulate critical thinking. For the adult student, civic education can discuss topics based on the condition that happens around them. Popular culture also can bring as a discus topic this can be done because the adult student has become part of the society and more understand their roles. Value and moral awareness for adult students are from their experience in society and needed to be stimulated by a real condition around them. In this case, media can be useful to provide a real image for the student to experience. A problem can arise if there is a lack of response from the lecture. So communication is essential for distance education to work, so the student and lecture must discipline to the schedule that has been made. Therefore distance education for civic education is needed to provide: 1) stimulate critical thinking, 2) topic based on the real condition, 3) popular culture as discuss a topic, 4) quick response from the lecture. To provide that lecture need the training to operate a system for distance education to develop a curriculum solely for distance education, so a further curriculum developed for distance education needs another research.

\section{REFERENCES}

[1] J. OHLER, "Why Distance Education?," Ann. Am. Acad. Pol. Soc. Sci, vol. 514, no. 1, pp. 22-34, Mar. 1991, 
doi: $10.1177 / 0002716291514001003$.

[2] A. A. Wahab and Sapriya, Teori \& Landasan Pendidikan Kewarganegaraan. Bandung: Alfabeta, 2011.

[3] P. Crittenden, Jack and Levine, "Civic Education' The Stanford Encyclopedia of Philosophy," Metaphysics Research Lab, Stanford University, 2018. https://plato.stanford.edu/archives/fall2018 /entries/civic-education/.

[4] M. G. Moore and G. Kearsley, Distance education: A systems view of online learning. United State Of America: Wadsworth Publishing Company, 1996.

[5] K. M. Huebner and W. R. Wiener, "Distance Education in 2001," J. Vis. Impair. Blind., vol. 95, no. 9, pp. 517-524, Sep. 2001, doi: 10.1177/0145482X0109500902.

[6] S. Yao, D. Li, A. Yohannes, and H. Song, "Exploration for network distance teaching and resource sharing system for higher education in epidemic situation of COVID19," Procedia Comput. Sci., vol. 183, pp. 807-813, 2021, doi: https://doi.org/10.1016/j.procs.2021.03.002

[7] C. D. Lawrence, "Turney C (ed). Innovation in teacher education: a study of the directions, processes and problems of innovation in teacher preparation with special reference to the Australian context and to the role of cooperating schools. Sydney, University Press 1977," Education, vol. 59 , no. 18 , p. $416,1978$.

[8] J. Cogan and Derricot, Citizenship for The 21 Century: An International Perspective on Education. London: Cogan Page, 1998.

[9] Undang-Undang Republik Indonesia Nomor 12 Tahun 2012 tentang Pendidikan Tinggi. .

[10]R. RISTEKDIKTI, "PENDIDIKAN KEWARGANEGARAAN untuk Perguruan Tinggi," 2016.

[11] K. P. D. A. N. KEBUDAYAAN and R. INDONESIA, "Pendidikan Pancasila dan Kewarganegaraan," 2014.

[12] Kaelan and A. Zubaidi, Pendidikan Kewarganegaraan. Yogyakarta: Paradigma, 2010.

[13] Y. Latif, Negara Paripurna, 4th ed. Jakarta: Gramedia, 2012.

[14] J. L. Moore, C. Dickson-Deane, and K.
Galyen, "e-Learning, online learning, and distance learning environments: Are they the same?," Internet High. Educ., vol. 14, no. 2, pp. 129-135, 2011, doi: https://doi.org/10.1016/j.iheduc.2010.10.00 1.

[15] I. H. Buchen, "Customizing Online Learning," World Futur. Rev., vol. 4, no. 2, pp. 179-181, May 2012, doi: $10.1177 / 194675671200400222$.

[16] J. Vivolo, "Understanding and Combating Resistance to Online Learning," Sci. Prog., vol. 99, no. 4, pp. 399-412, Dec. 2016, doi: 10.3184/003685016X14773090197742.

[17] W. Journell, "Walk, Don't Run - to Online Learning," Phi Delta Kappan, vol. 93, no. 7, pp. 46-50, Apr. 2012, doi: $10.1177 / 003172171209300711$.

[18] M. A. Maddix, "Developing Online Learning Communities1," Christ. Educ. J., vol. 10, no. 1, pp. 139-148, May 2013, doi: 10.1177/073989131301000111.

[19] S. B. Waschull, "Predicting Success in Online Psychology Courses: Self-Discipline and Motivation," Teach. Psychol., vol. 32, no. 3, pp. 190-192, Jul. 2005, doi: 10.1207/s15328023top3203 11.

[20]A. L. Duckworth, "Self-Discipline is Empowering," Phi Delta Kappan, vol. 90, no. 7, p. 536, Mar. 2009, doi: $10.1177 / 003172170909000720$.

[21] H. M. Sharp, "Student Self-Discipline: Helping Students Behave Responsibly. By Stanley T. Dubelle. Rockport, Mass.: Pro>Active Publications, 1995," NASSP Bull., vol. 81, no. 591, pp. 115-116, Oct. 1997, doi: 10.1177/019263659708159119.

[22] Joel R and A. Mathur, "The value of online surveys: a look back and a look ahead," Internet Res., vol. 28, no. 4, pp. 854-887, Jan. 2018, doi: 10.1108/IntR-03-2018-0089.

[23] J. Dewey, The school and society. In Dewey on education. New York: Teachers College Press, 1959.

[24] D. R. Garrison, M. Cleveland-innes, and T. Shing, "Internet and Higher Education Exploring causal relationships among teaching, cognitive and social presence: Student perceptions of the community of inquiry framework," Internet High. Educ., vol. 13 , no. $1-2$, pp. $31-36,2010$, doi: 10.1016/j.iheduc.2009.10.002. 
[25] J. Mezirow, "Perspective Transformation," Adult Educ., vol. 28, no. 2, pp. 100-110, Jan. 1978, doi: $10.1177 / 074171367802800202$.

[26] J. A. Sandlin, R. R. Wright, and C. Clark, "Reexamining Theories of Adult Learning and Adult Development Through the Lenses of Public Pedagogy," Adult Educ. Q., vol. 63, no. 1, pp. 3-23, Aug. 2011, doi: $10.1177 / 0741713611415836$.

[27] T. Lickona, Character Matters: How to Make Our Children Develop Good Judgment, Integrity, and Other Essential Virtue. Jakarta: Bumi Aksara, 2013.

[28] M. I. Farisi, “Academic dishonesty in distance higher education: Challenges and models for moral education in the digital era," Turkish Online J. Distance Educ., vol. 14, no. 4, pp. 176-195, 2013. 